\title{
Building reputation through sustainable supplier selection: the case of an emerging economy
}

Sustainable supplier selection

Mohammad Asif Salam

Department of Business Administration, Faculty of Economics and Administration, King Abdulaziz University, Jeddah, Saudi Arabia, and Murad Ali

Department of HRM, Faculty of Economics and Administration, King Abdulaziz University, Jeddah, Saudi Arabia

Received 2 December 2019 Revised 23 February 2020 2 March 2020 16 March 2020

Accepted 17 March 2020

\begin{abstract}
Purpose - The purpose of this research is to examine the drivers of sustainable supplier selection (SSS) and investigate the extent to which it is associated with a buyer's financial performance within an emerging economy context.

Design/methodology/approach - The data were collected from 235 supply chain and procurement professionals in Thailand. The structural relationship was tested using partial least squares based structural equation modeling (PLS-SEM) and PROCESS tool.

Findings - Based on the empirical findings, firms that pursue sustainability initiatives during supplier selection process enjoy better financial performance than their competitors. The analysis suggests six hypothetical paths explain SSS. Suppliers' human rights and safety focus are the most powerful determinants of SSS. Significantly, positive support was found for the SSS and buyers' financial performance relationship. Finally, there is a significant moderating effect of resource investment on sustainability efforts.

Research limitations/implications - Data for the study were collected from a single industry, so the findings are indicative but not representative of all supply chains. Due to this limitation, the findings cannot be generalized across other countries and industries. This study is a starting point in understanding the role of SSS in creating a sustainable supply chain. Future research may develop a comprehensive understanding of the nature and magnitude of the impact of SSS on sustainable supply chains.

Originality/value - This paper contributes toward an understanding of the determinants of SSS and its consequences for sustainable supply chains.
\end{abstract}

Keywords Sustainable supplier selection, Purchasing social responsibility, Financial performance, Supply chain management, Stakeholder theory

Paper type Research paper

\section{Introduction}

Many of the global supply chains rely on emerging economy suppliers for their sourcing decisions due to various reasons, such as close proximity to markets, close proximity to manufacturers, quality, delivery, flexibility and skilled and low-cost labors. In recent years, the reputations of many organizations have been at stake by the questionable practices of their suppliers owing to sustainability issues (Foerstl et al, 2015). There is ample anecdotal evidence suggesting that firms can suffer severe losses due to social, ecological or ethical problems hidden in their supply chains. To make things even worse, they know very little about the

(C) Mohammad Asif Salam and Murad Ali. Published in European Journal of Management and Business Economics. Published by Emerald Publishing Limited. This article is published under the Creative Commons Attribution (CC BY 4.0) licence. Anyone may reproduce, distribute, translate and create derivative works of this article (for both commercial and non-commercial purposes), subject to full attribution to the original publication and authors. The full terms of this licence may be seen at http:// creativecommons.org/licences/by/4.0/legalcode

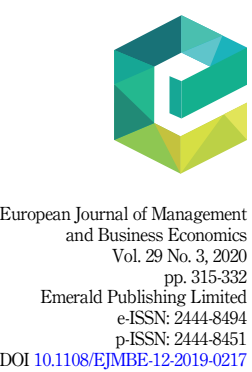


EJMBE 29,3 magnitude of sustainability issues that emerge as risks and how those risks eventually impact focal firms to suffer losses (Hofmann et al, 2014). For example, Chowdhury (2017) describes the Rana Plaza (Bangladesh) tragedy which triggered international outrage, forcing reputable US and European clothing brands to improve safety conditions at their supplier factories. Incidents such as these emphasize the need for more research into supplier selection, social responsibility and sustainability. Despite the renewed call for research focusing on sustainability in purchasing and supply management (Thornton et al., 2013; Kumar and Rahman, 2016), the challenges of identifying sustainable suppliers are still under-explored.

The process to sustainable supply chain practice begins with sustainable suppliers. Carter and Easton (2011) suggest that firms should not select suppliers purely based on price, delivery and service quality but also on their ability to integrate sustainability into their business practices. Buying firms are paying close attention to sustainability compliance as scandals can damage their business (Koplin et al., 2007). Reuter et al. (2010, p. 46) defined sustainability as "the tripartite pursuit of economic, ecological, and social performance," which Elkington (1998) named the "triple bottom line" of an organization. The purpose of this study is to explore the drivers of sustainable supplier selection (SSS) and its impact on firms' financial performance. Donaldson and Preston (1995) argued that commitment to sustainability comes at a cost, and stakeholder pressures are the drivers of SSS phenomena in the supply chain. Building on stakeholder theory, the current study addresses the SSS issue by examining how socially responsible purchasing practices which are measured by the purchasing social responsibility (PSR) dimensions, such as customers, the government, employees and the society at large as primary constituencies of the firm, determine the extent to which firms consider sustainability aspects in the selection of emerging economy suppliers. Further, we analyze how SSS relates to the firm's financial performance, which eventually reflects its market reputation.

On this backdrop, current study aims to examine the role of SSS on financial performance within an emerging economy context by addressing three research questions: (1) What are the links between the purchasing social responsibility (PSR) and SSS? (2) Is SSS associated with firms' financial performance? (3) Does a firm's investment in sustainability programs impact the SSS-financial performance relationship? To approach these research questions, the researchers develop a research framework using stakeholder theory.

\section{Literature review}

\subsection{Purchasing social responsibility (PSR)}

Carroll (1979) defined PSR as "purchasing activities that meet the ethical and discretionary responsibilities expected by society." Carter and Jennings (2004) examined the role of PSR in supply chain management, theoretically and empirically. The dimensions of PSR include diversity, environment, ethical or fair treatment, human rights, community focus and safety. The dimensions of PSR are closely related to those of corporate social responsibility (CSR) and embedded within the central tenets of stakeholder theory. Consumer perception of a firm's CSR activities positively influences their view of the company, customer satisfaction, loyalty and hence financial performance (Feng et al., 2017).

Global sourcing has become a prominent topic in the field of purchasing and supply management (PSM) and leads to the emergence of PSR (Monczka et al., 2008). Moreover, Munro et al. (2018) also argue that CSR initiatives must be relevant to stakeholders and local market needs. Hence, sustainability encompasses the tripartite pursuit of economic, environmental and social performance, the triple bottom line (Carter and Rogers, 2008). The PSR makes the firm responsible for sustainable processes on suppliers' premises. Any failure or irresponsible actions of suppliers reflect on the buying firm, and may lead to loss of reputation and legal obligations (Koplin et al., 2007; Panahifar et al., 2018). In line with earlier studies by Carroll 
(1979), Carter and Jennings (2004), Munro et al. (2018) and Carter and Rogers (2008), in this study, PSR has been defined as a set of purchasing practices that encompass the ecological, social, ethical, economic and discretionary responsibilities expected by society.
Sustainable supplier selection

\subsection{Sustainable supplier selection (SSS)}

The term sustainability encompasses an integration of social, environmental and economic responsibilities. In a McKinsey and Co. (2014) global survey, $43 \%$ of 3,344 executives representing the full range of industries, regions, company sizes and functional specialties reported their companies seek to align sustainability with their overall business. This result was up from $30 \%$ in 2012. Sustainable supplier selection (SSS) is a critical step toward creating a sustainable supply chain which is defined by Carter and Rogers (2008) as, "the strategic, transparent integration and achievement of an organization's social, environmental and economic goals in the systemic coordination of key inter-organizational business processes for improving the long-term economic performance of the individual company and its suppliers [and customers]" (p. 368). Drawing on the extant literature (e.g., Carter and Jennings, 2004, 2002a, b; Walker and Jones, 2012), the central focus of this study is to integrate supplier selection, PSR and sustainability in the supply chain, and link them to a firm's financial performance through SSS.

SSS is treated as a multidimensional construct and based on studies by Walker and Jones (2012) and Thornton et al. (2013), in this study, SSS is defined as, a firm's strategic orientation and transparent commitment toward selecting suppliers who are capable of delivering materials through business processes that are environmentally safe, socially responsible and economically viable for improving the long-term performance of entire supply chain. This definition combines supplier selection, sustainability and PSR in the field of supply chain management. SSS has been operationalized as a higher-order construct and formative construct including six sub-dimensions adapted from Carter and Jennings (2008; 2004; 2002a and b). These dimensions are diversity, environmental, supplier ethical treatment, human rights, philanthropy, safety and commitment to sustainability.

In the sustainable supply chain management (SSCM) stream of research, studies have analyzed the impact of suppliers' practices on buyers' financial performance. Thornton et al. (2013) found a relationship between socially responsible supplier selection and buyer performance. However, the study addressed only the social dimension of sustainability using buyers' aggregate practices. This study goes further and considers the ecological, social and economic roles of supplier selection in financial performance. This study provides sustainable supplier selection measures rather than the aggregate practices of the buyer, and analyzes the causal mechanisms through which changes in the SSS influence the buyer's performance.

\subsection{Linking PSR dimensions and SSS}

Supplier's environmental awareness is a prerequisite for socially responsible sourcing. According to Carter and Jennings (2002a) and Carter and Rogers (2008), socially responsible firms ensure that supplier processes and products are environmentally sound. Carter and Jennings (2004) and Carter and Rogers (2008) argued environmental awareness will lead to successful implementation of an SSS initiative. This argument leads to the first research question and related hypotheses (H1-H6):

H1. There is a positive association between a supplier's environmental focus and SSS implementation.

Suppliers must be judged to be hones/ethical during the supplier selection process (Thornton et al., 2013; Carter and Jennings, 2004). According to Carter and Jennings (2002b), unethical behavior includes lying, misleading or blaming suppliers' representatives for mistakes that 
EJMBE 29,3

were not their fault. Munro et al. (2018) found fairness in the treatment of suppliers' leads to the successful implementation of SSS. This argument leads to the second hypothesis:

H2. There is a positive association between supplier's ethical treatment and SSS implementation.

Supplier's diversity reflects the extent to which the firms select suppliers belonging to gender or ethnic minority groups (Carter and Jennings, 2004). Firms can play a crucial role by contributing to the development of disadvantaged groups in the society. According to Carter et al. (1999), sourcing from minority-owned suppliers plays a key role in strengthening their economic outlook. Carter and Rogers (2008) proposed greater supplier diversity leads to the successful implementation of SSS. This argument leads to the third hypothesis:

H3. There is a positive association between supplier's diversity focus and SSS implementation.

The supplier's human rights dimension represents the extent to which firms actively seek suppliers who emphasize human social issues during normal operations (Carter and Jennings, 2004). According to Culpan et al. (2010), as supply chains become more globalized, interest in human rights and ethical treatment of workers by overseas suppliers is growing. Carter and Jennings (2004) and Carter and Rogers (2008) found increased respect for human rights leads to successful implementation of SSS. This argument leads to the fourth hypothesis:

H4. There is a positive association between a supplier's human rights focus and SSS implementation.

The supplier's safety dimension captures the emphasis firms place on potential suppliers' safety-related behavior (Carter and Jennings, 2004). A safe workplace can only be achieved by strict enforcement of safety measures. The significant increase in the number of industrial accidents (Yuan et al., 2010) and work-related injuries (Yu et al., 2012; Chowdhury, 2017) in countries such as China and Bangladesh highlights the need for scrutiny of the potential suppliers' safety conditions and standards. Strict enforcement of safety measures by supplier leads to successful implementation of SSS. This argument leads to the fifth hypothesis:

H5. There is a positive association between supplier's safety focus and SSS implementation.

The supplier's community focus dimension reflects the extent to which firms consider the impact of their supplier choice on the broader community (Carter and Jennings, 2004; Thornton et al., 2013). Firms should consider the involvement of local suppliers and support them. Carter and Jennings (2002a) argue that firms can positively impact the local community by selecting and supporting local suppliers. This argument leads to the sixth hypothesis:

H6. There is a positive association between supplier's community focus and SSS implementation.

\subsection{Linking SSS and financial performance}

The focus of this study is to investigate empirically the extent to which buyer firms benefit financially from engaging in SSS. SSS is positively related to firms' long-term performance, which includes reputation, loyalty, innovativeness, lead time, quality and responsiveness (Blome et al., 2014). In this case, firms' reputation is reflected through its financial performance due to the fact that the firm capitalizes on its image, "doing well, by doing good." The link between SSS and its outcome can be explained by stakeholder theory. Studies by Preston and O'bannon (1997), McGuire et al. (1988) and Cochran and Wood (1984) linked sustainable supplier behavior to economic performance. A firm's business activities are not 
always governed by the shareholders' desires, but by supply chain partners and society as a whole. External stakeholders influence the firm and the supply chain, by ensuring that the firm undertakes activities that go beyond the profit-oriented view of shareholders. Firms that consider external stakeholders' interests in making an ethical decision may gain supernormal returns, if those decisions align with internal stakeholder interests (Freeman et al., 2004; Donaldson and Preston, 1995). Carter and Jennings (2004) found a link between PSR practices and financial viability in their meta-analysis.

Based on morality shared end-users, Thornton et al. (2013) argue that financial performance improves as firms employ SSS. Carter and Rogers (2008) argue that many firms have recently begun to focus on sustainable supply chain issues, and it seems likely that SSS will be a strong predictor of financial performance. This argument leads to the second research question and related hypothesis: What is the relationship between SSS and a firm's financial performance?

H7. There is a positive association between SSS and financial performance.

Chandler (1962) proposed contingency theory suggesting that there are numerous ways that firms may choose to maximize their performance, depending on how they allocate their limited resources. In line with the strategy-structure-performance (SSP) paradigm, Galbraith and Nathanson (1978) argue that a firm's strategy to match with environmental factors will drive the improvement of organizational structure and processes. Miles and Snow (1984) postulate that firms that have proper strategic alignment should perform better. Following this line of argument, firms that strategically pursue SSS will gain more profit. The third research question addresses this, examining the hypothesized moderating effect: Does a firm's investment in sustainability programs impact the SSS-financial performance relationship?

H8. There is a moderating effect of a firm's resource investment in social programs on the relationship between SSS and financial performance.

The research model integrating all the hypothesized relationships among variables discussed above is summarized in Figure 1.

\section{Methodology}

\subsection{Measurement instrument}

All six dimensions of PSR scales were adapted to form the exogenous variables and measured by scales developed by Carter and Jennings (2004). These six exogenous variables are supplier's diversity focus, supplier's environmental focus, supplier's ethical treatment, supplier's human rights focus, supplier's community focus and supplier's safety focus. The resultant scales are designed to achieve the needs of organizational stakeholders while simultaneously considering ecological, social and economic constraints (Chow and Chen, 2012). The respective measures and SSS dimensions are shown in Table 1. To validate the SSS construct, the researchers followed the literature (e.g. Carter and Jennings, 2008; 2004; 2002a,b; Foerstl et al., 2015; Thornton et al., 2013) and tested its correlation with financial performance. We adopted three items from Thornton et al. (2013) to measure buyers' financial performance: (1) comparing sales revenue with other firms in their industry, (2) comparing sales growth with other firms in their industry and (3) comparing change in market share with other firms in their industry.

The questionnaire based on these SSS measures and financial performance measures was developed. We measured SSS using a 7-point Likert scale ranging from 1 (None whatsoever) to 7 (To a very great extent). We measured financial performance by using a 7-point Likert scale ranging from 1 (Much worse) to 7 (Much better). Although the questionnaire was originally developed in English, it was subsequently translated into Thai to facilitate 


\section{EJMBE}

29,3
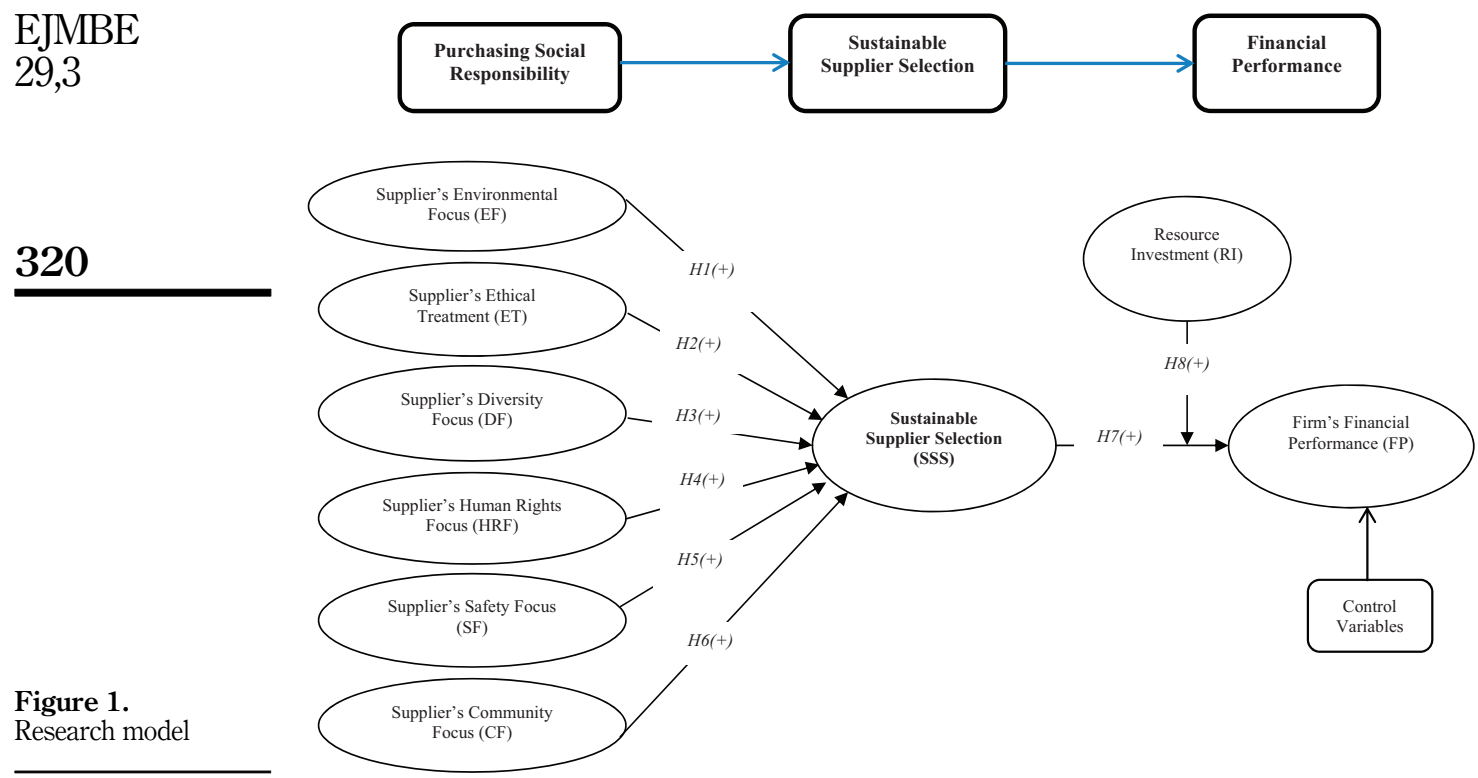

respondents' understanding. We followed the approach of Bhalla and Lin (1987) and ensured the linguistic equivalence of the two versions by using the back-translation technique. All measures were professionally translated and back-translated to ensure conceptual equivalence. A pretest was carried out with local professors to refine the measurement items. Using their feedback, we improved the final version of the questionnaire. Table 1 presents the questionnaire on the SSS dimensions and their measures.

SSS in this study has been treated as a mediating variable. Construct correlations are presented in Table 2. It was concluded that all scales were valid and reliable. The moderating effect of resource investment in social programs was included to determine whether tangible investments would financially differentiate firms from those adopting SSS principles but without investing in any other programs. The social program investment variable was composed of a four-item scale tapping investments in (1) SSS-related technology/innovations, (2) resource endowment to benefit underprivileged social groups, (3) providing jobs for the disabled, (4) supporting education/culture/arts programs, (5) investing in local economic development and (6) investing in national economic development. The social program investment scales were adopted from Thornton et al. (2013).

Control Variables. Due to the possible impact of external environmental and internal firmlevel characteristics on the relationships between SSS and its dimensions and firm-level outcomes, several control variables were included. These measures were reflected by the workforce size (number of employees), age and annual revenue at the company level, along with an industry sector and ownership structure. The detailed description of control variables is given in Table 1.

\section{Data analysis}

\subsection{Reliability analysis}

The assessment of the individual reliability of the items depends on examining the standardized factor loadings. A widely recognized rule of thumb is to accept items with 


\section{Constructs \\ Sustainable} supplier selection (SSS)

SR1
SR2
SR3
SR5
SR

Resource investment in social programs (RINV)
Supplier's diversity focus (SDF)

$\begin{array}{ll}\text { Code } & \text { Item wording } \\ & \text { Please indicate your }\end{array}$

choice on a scale $1=\mathrm{No}$ extent whatsoever to $7=$ Very great extent

$\begin{array}{lllll}\text { SR1 } & \text { We seek suppliers based } & 0.87 & 0.02 & 34.91\end{array}$ on their reasonability toward the environment $\begin{array}{lllll}\text { SR2 } & \begin{array}{l}\text { We seek suppliers based } \\ \text { on their reasonability }\end{array} & 0.91 & 0.01 & 64.24\end{array}$ toward diversity $\begin{array}{lllll}\text { SR3 } & \begin{array}{l}\text { We seek suppliers based } \\ \text { on their reasonability }\end{array} & 0.91 & 0.02 & 56.84\end{array}$ toward human rights

$\begin{array}{lllll}\text { SR4 } & \text { We seek suppliers based } & 0.89 & 0.02 & 38.76\end{array}$ on their reasonability toward philanthropy

$\begin{array}{lllll}\text { SR5 } & \text { We seek suppliers based } & 0.89 & 0.02 & 45.77\end{array}$ on their with reasonability toward safety

$\begin{array}{lllll}\text { SR6 } & \text { We seek suppliers based } & 0.76 & 0.04 & 21.56\end{array}$ on their commitment to sustainability by addressing/balancing environmental, social and economic perspectives in their business decisions

Please indicate your choice on a scale $1=$ Extremely unimportant to $7=$ Extremely important

\begin{tabular}{|c|c|c|c|}
\hline RINV1 & $\begin{array}{l}\text { Investment in SRSS- } \\
\text { related technology/ } \\
\text { innovations }\end{array}$ & 0.87 & 0.05 \\
\hline RINV2 & $\begin{array}{l}\text { Resource endowment to } \\
\text { benefit underprivileged } \\
\text { social groups }\end{array}$ & 0.98 & 0.02 \\
\hline RINV3 & $\begin{array}{l}\text { Providing jobs for the } \\
\text { disabled }\end{array}$ & 0.87 & 0.05 \\
\hline RINV4 & $\begin{array}{l}\text { Investing in local } \\
\text { economic development }\end{array}$ & 0.73 & 0.07 \\
\hline RINV5 & $\begin{array}{l}\text { Supporting education/ } \\
\text { culture/arts programs }\end{array}$ & 0.74 & 0.07 \\
\hline RINV6 & $\begin{array}{l}\text { Investing in national } \\
\text { economic development } \\
\text { Please indicate your } \\
\text { choice on a scale } \\
1=\text { Strongly disagree to } \\
7=\text { Strongly agree }\end{array}$ & 0.72 & 0.09 \\
\hline SDF1 & $\begin{array}{l}\text { We try to choose } \\
\text { suppliers that are owned } \\
\text { by minority ethnic } \\
\text { groups/women }\end{array}$ & 1.00 & 0.00 \\
\hline
\end{tabular}

Sustainable supplier selection 


\section{EJMBE} 29,3

\section{2}

\begin{tabular}{|c|c|c|c|c|c|c|c|c|c|}
\hline Constructs & Code & Item wording & S.L & S.E & $t$-value ${ }^{1,2}$ & $A$ & C.R & $\mathrm{AVE}^{3}$ & VIF \\
\hline \multirow[t]{5}{*}{$\begin{array}{l}\text { Supplier's } \\
\text { environmental } \\
\text { focus (SEF) }\end{array}$} & & $\begin{array}{l}\text { Please indicate your } \\
\text { choice on a scale } \\
1=\text { Strongly disagree to } \\
7=\text { Strongly agree }\end{array}$ & & & & 0.83 & 0.88 & 0.66 & 2.30 \\
\hline & SEF1 & $\begin{array}{l}\text { We try to choose } \\
\text { suppliers whose } \\
\text { processes/products are } \\
\text { environmentally safe }\end{array}$ & 0.91 & 0.01 & 65.9 & & & & \\
\hline & SEF2 & $\begin{array}{l}\text { We try to choose } \\
\text { suppliers that use } \\
\text { recyclable/reusable } \\
\text { packaging }\end{array}$ & 0.94 & 0.01 & 87.92 & & & & \\
\hline & SEF3 & $\begin{array}{l}\text { We try to choose } \\
\text { suppliers who } \\
\text { participate in green } \\
\text { purchasing initiative }\end{array}$ & 0.56 & 0.07 & 8.18 & & & & \\
\hline & SEF4 & $\begin{array}{l}\text { We try to choose } \\
\text { suppliers that create as } \\
\text { little waste as possible }\end{array}$ & 0.79 & 0.04 & 19.18 & & & & \\
\hline Supplier's ethical & & Please indicate your & & & & 0.87 & 0.91 & 0.72 & 2.41 \\
\hline
\end{tabular}

Supplier's human rights focus (SHR) treatment (SET) choice on a scale $1=$ Strongly disagree to $7=$ Strongly agree

$\begin{array}{lllll}\text { SET1 } & \text { We avoid tactics that } & 0.82 & 0.03 & 23.65\end{array}$ could mislead supplier salespeople during negotiations

SET2 We never lie or exaggerate when negotiating with suppliers
SET3 We avoid blaming suppliers for mistakes that were our own fault

SET4 We avoid using terms in our supply contracts that would allow us to take unfair advantage of suppliers Please indicate your choice on a scale $1=$ Strongly disagree to $7=$ Strongly agree

\begin{tabular}{|c|c|c|c|c|}
\hline & $\begin{array}{l}1=\text { Strongly disagree to } \\
7=\text { Strongly agree }\end{array}$ & & & \\
\hline SHR1 & $\begin{array}{l}\text { We try to choose } \\
\text { suppliers that do not use } \\
\text { sweatshop labor }\end{array}$ & 0.89 & 0.02 & 42.52 \\
\hline SHR2 & $\begin{array}{l}\text { We try to choose } \\
\text { suppliers that do not use } \\
\text { child labor }\end{array}$ & 0.90 & 0.02 & 51.25 \\
\hline SHR3 & $\begin{array}{l}\text { We try to choose } \\
\text { suppliers that pay their } \\
\text { employees a fair wage to } \\
\text { live on }\end{array}$ & 0.93 & 0.01 & 84.46 \\
\hline SHR4 & $\begin{array}{l}\text { We try to choose } \\
\text { suppliers that support } \\
\text { human rights }\end{array}$ & 0.87 & 0.02 & 40.63 \\
\hline
\end{tabular}




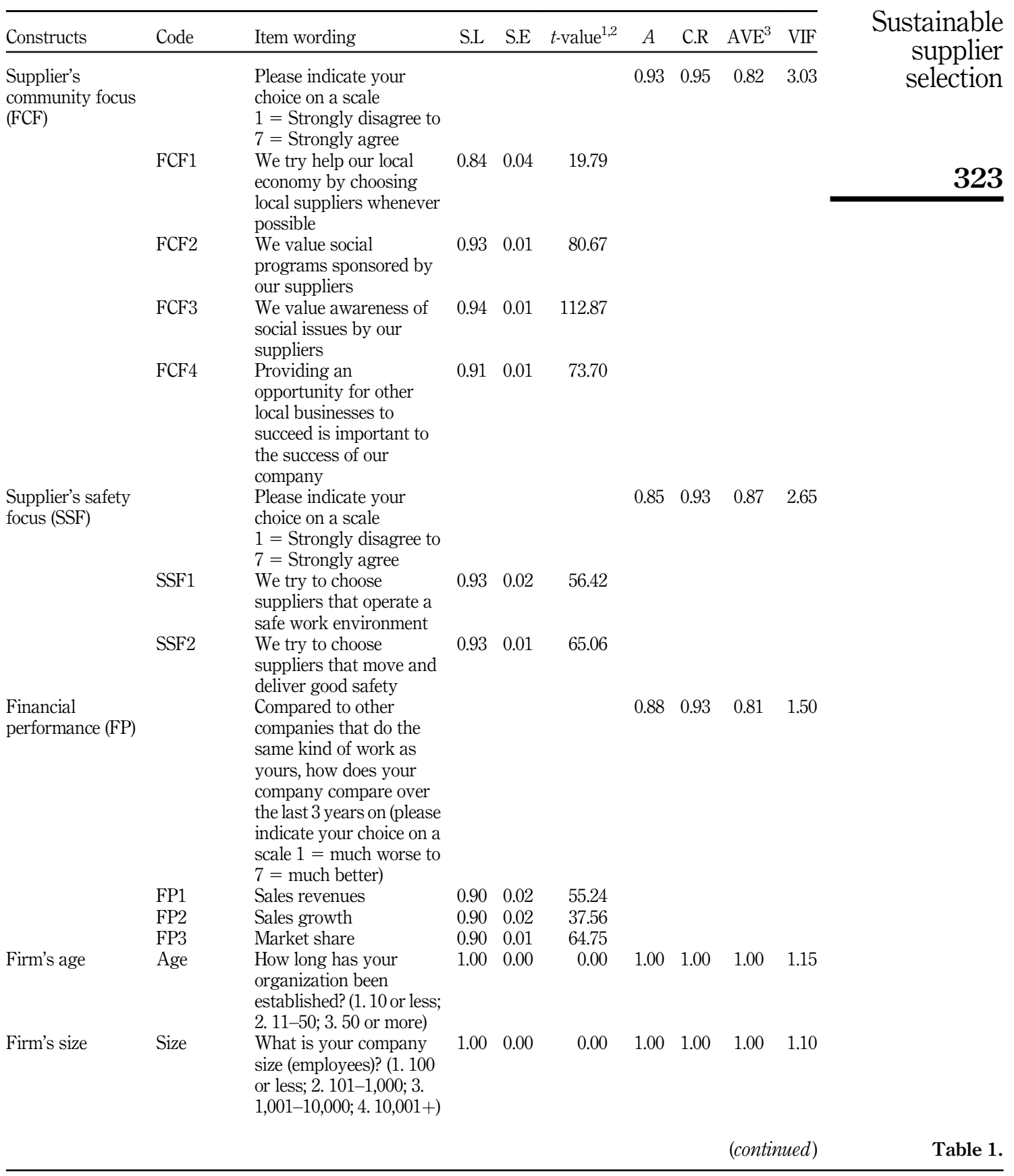




\section{EJMBE 29,3}

\begin{tabular}{lllllllllll}
\hline Constructs & Code & Item wording & S.L & S.E & $t$-value & 1,2 & $A$ & C.R & AVE $^{3}$ & VIF \\
\hline Annual revenue & Revenue & $\begin{array}{l}\text { How large is your } \\
\text { organization (annual }\end{array}$ & 1.00 & 0.00 & 0.00 & 1.00 & 1.00 & 1.00 & 1.01
\end{tabular}

\section{4}

Industry type Industry

revenues)? (1. $\$ 0$ to

$\$ 250 \mathrm{M} ; 2$. $\$ 250$ to $\$ 500 \mathrm{M}$;

3. $\$ 500 \mathrm{M}$ to $\$ 1 \mathrm{~B} ; 4$. $\$ 1 \mathrm{~B}$ to

$\$ 3 \mathrm{~B} ; 5 . \$ 3 \mathrm{~B}+$ )

Which category best

$1.00 \quad 0.00$

$\begin{array}{llll}0.00 & 1.00 & 1.00 & 1.00\end{array}$

1.07

describes your

organization's primary

industry? (1. Supplier; 2.

Manufacturer; 3.

Distributor; 4. Retailer; 5.

Transportation; 6 .

Mineral Resource; 7.

Other)

Ownership Ownership $\begin{aligned} & \text { Please indicate the } \\ & \text { ownership structure of }\end{aligned}$

$\begin{array}{lllllll}1.00 & 0.00 & 0.00 & 1.00 & 1.00 & 1.00 & 1.09\end{array}$

your organization. (1.

Private; 2. Public; 3. Joint

-Public/Private)

Note(s): 'B' stands for Baht, the name of Thai currency. I baht $=32 \$ \mathrm{US}$

$\mathrm{S} . \mathrm{L}=$ Standard loadings; S.E = Standard error; ${ }^{1}$ Test-statistics are obtained by 5,000 Bootstrap runs;

${ }_{2}$ Absolute $t$-values $>1.96$ are two-tailed significant at $5 \% ; \alpha=$ Cronbach's alpha; C.R = Composite reliability;

Table 1. $\mathrm{AVE}=$ Average variance extracted; ${ }^{3}$ Percentage of variance of item explained by the latent variable; VIF = Variance inflation factor

loadings of 0.80 (Fornell and Larcker, 1981), while loadings 0.50 or greater are considered practically significantly for exploratory research (Nunnally, 1978). In Table 1, the standardized factor loadings for each measurement item are provided. The $t$-test of all the loadings is at the $p<0.001$ level. All the loadings are above this minimum. The reliability and convergent validity of the constructs are evaluated by analyzing the Cronbach's alpha and composite reliability of the indicator. Nunnally (1978) recommends a value of 0.80 as a threshold value for this indicator. The Cronbach's alpha scores ranged between 0.654 and 0.865 , while the composite reliability scores ranged between 0.76 and 0.93 , indicating adequate convergence or internal consistency. Table 2 shows the means, SD, minimum and maximum values of the response option of the scales, the correlation for all the constructs and the square root of the AVE on the diagonals. Mean values indicate that most constructs are above their respective mid-point, while correlations among the independent constructs are relatively low. Thus, multicollinearity was not a concern in this study (Hair et al., 2010).

\subsection{Validity analysis}

The average variance extracted (AVE) provides an assessment of convergent validity. Fornell and Larcker (1981) recommend an AVE value $\geq 0.5$. This means that $50 \%$ or more of the indicator variance should be accounted for. Consistent with this suggestion, all the constructs have an AVE value above this minimum as shown in Table 1. This study follows three approaches to assess the discriminant validity, that is: (1) Fornell-Larcker criterion, (2) cross-loading and (3) the heterotrait-monotrait ratio of correlations (HTMT). The correlation matrix in Table 2 shows that for each pair of constructs, the AVE square root of each construct (see Table 2 values on the diagonal) is higher than the absolute value of their 


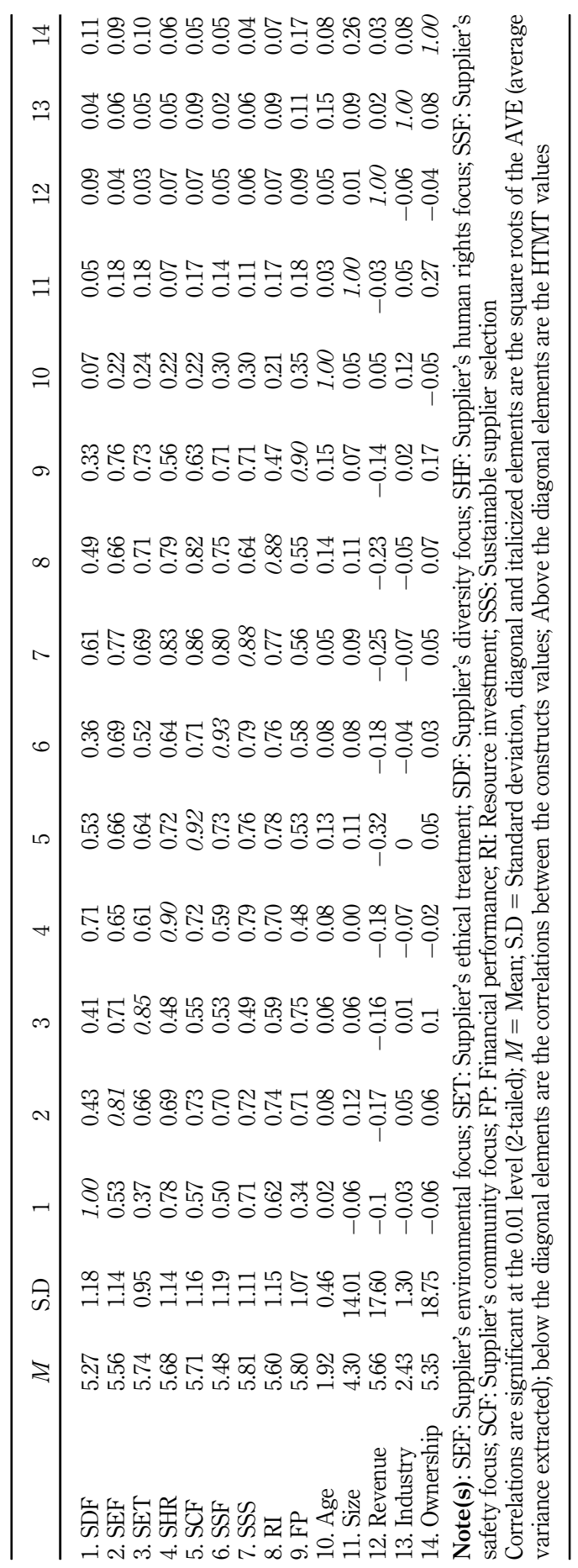

Sustainable supplier selection

325

Table 2. Descriptive statistics, correlations, square root of AVE and HTMT analysis results 
EJMBE 29,3 correlation (Fornell and Larcker, 1981). The results of cross-loading indicate that all items loaded higher on their respective constructs than on the other constructs and the crossloading differences are much greater than the suggested threshold of 0.1 (Gefen and Straub, 2005). In all cases, the HTMT values are below the threshold of 0.85 or 0.90 as shown in Table 2. These results confirm that the discriminant validity is present in this study.

\subsection{Analysis of structural model}

4.3.1 Evaluation of the overall model predictability. This study follows Hair et al. (2017) to estimate the structural model using partial least squares based structural equation modeling (PLS-SEM) technique. This study assesses the structural model for collinearity. The results show minimal collinearity in the structural model as all variance inflation factor (VIF) values are far below the common cutoff threshold of 5-10 (Hair et al., 2017). The structural model predictability is computed using variance explained $R^{2}$ values for the dependent latent constructs. The $R^{2}$ values of SSS is 0.83 , and for FP is 0.54 , as shown in Table 3 , which is a satisfactory level of predictability. Following Hair et al. (2017), the significance levels of the path coefficients were obtained using the bootstrapping procedure (with 5,000 bootstrap samples and 235 bootstrap cases, using individual sign changes). The analysis of path coefficients and levels of significance of all direct relationships shows that H3-H7 were accepted while $\mathrm{H} 1$ and $\mathrm{H} 2$ were not accepted, as shown in Table 3(a).

Finally, the blindfolding procedure was run to compute the model's predictive relevance. Table 3 provides the $Q^{2}$ values of all the dependent constructs which are considerably above zero, thus providing support for the model's predictive relevance. This study follows Henseler et al. (2014) and refers to the standardized root mean square residual (SRMR) as an index for overall model fit validation. Scholars consider values below 0.08 as favorable (Hu and Bentler, 1999 ) in this instance. While the model estimation with PLS-SEM reveals an SRMR value of 0.07 as shown in Table 3, which confirms the overall fit of PLS-SEM (Hair et al., 2017; Henseler et al., 2014).

\subsection{Analysis of moderating effect}

This study employed a computational procedure in SPSS using the PROCESS macro developed by Hayes (2013), to test for moderation (H8). This procedure not only implements moderation or mediation analysis, but also combines both to determine the significance of the interaction effects at different values of the moderator in an integrated moderated mediation model (Hayes, 2013). This study used PLS latent variables scores in PROCESS for moderation analysis. The moderating effect of RI on the indirect relationships between PSR and FP via SSS was statistically significant $(\beta=0.35, t=7.55)$, in support of $\mathrm{H} 8$.

Table 3(b) shows that RI moderates the relationship between SSS and FP which necessitates examining the effect of SSS on FP with changes in RI. Next, this study examined RI at three levels to determine if the indirect relationships associated with SSS varied at different levels of RI. In other words, a simple slope analysis is used to estimate the effect on the main variable (SSS) at the moderate $(M=5.60, \mathrm{S.D}=1.15)$ one SD below the mean ( -1 S.D; i.e. 4.45) and one SD above the mean (+1 S.D; 6.75$)$ levels of the moderator, RI (Hayes, 2013). All variables were mean-centered before analysis. Consistent with H8, Table 3(c) shows that when RI was low ( -1 S.D), the conditional indirect effect (via SSS) of PSR on FP was positive and significant but weak $(\beta=0.29$, boot $\mathrm{SE}=0.07$ ). However, when RI was high ( +1 S.D), the conditional indirect effect was both positive and significant $(\beta=0.99$, boot $\mathrm{SE}=0.09)$. These findings support the notion of the H8, which means as the influence of the mediating role of SSS increases, the effect of RI increases even to a more considerable extent. As shown in Figure 2, the relationship between SSS and financial performance is lower when RI is low, and stronger when RI is high. 


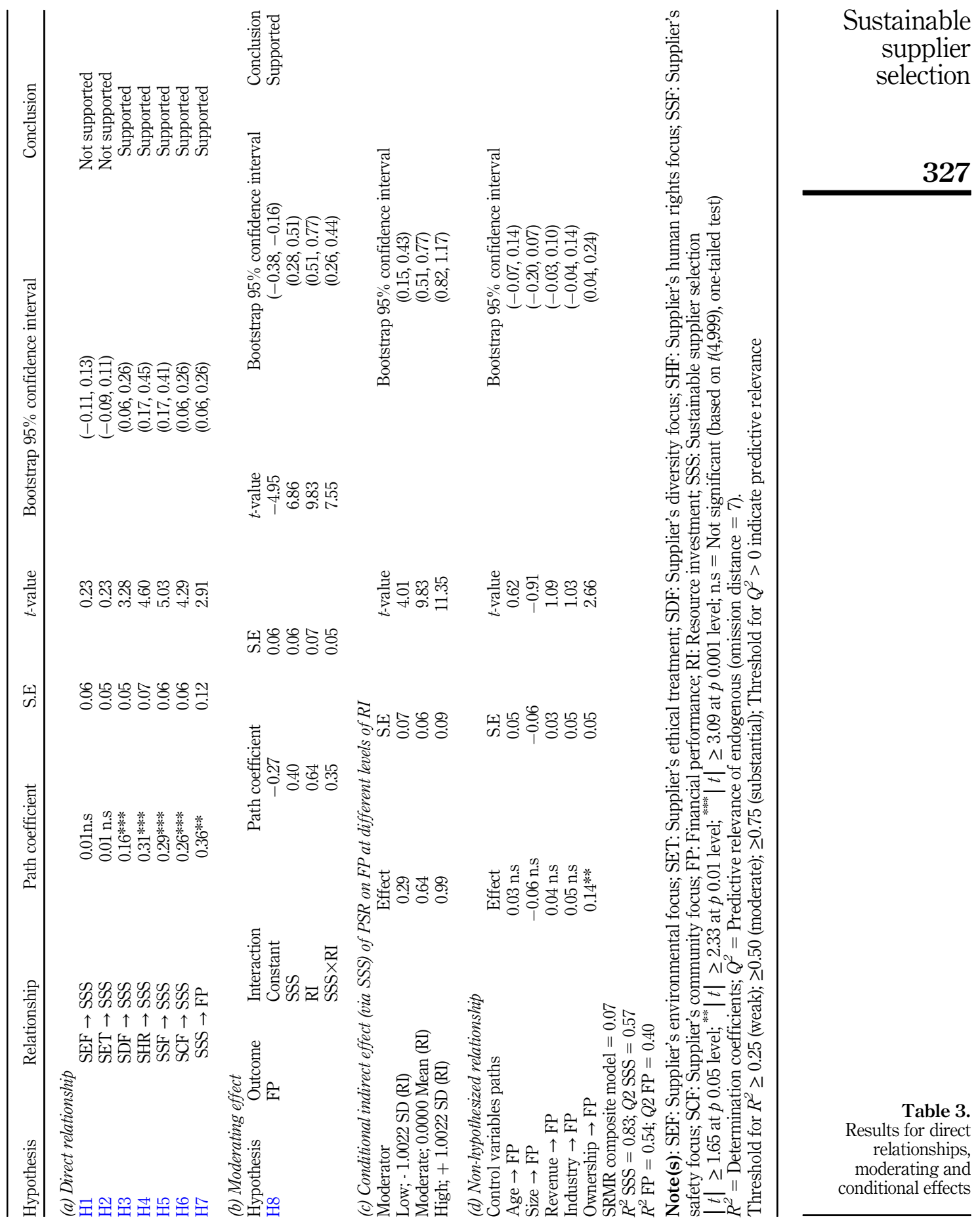


EJMBE 29,3

\section{8}

Figure 2.

Moderating effect of RI on the relationship between SSS and FP (see online version for colors)

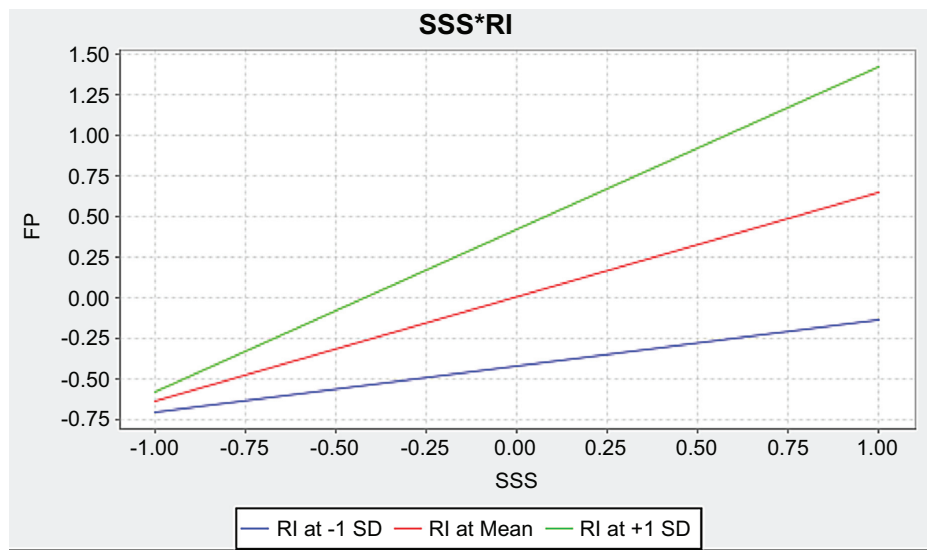

\section{Conclusion and research implications}

The SSS is a legitimate concern for the businesses while dealing with off-shore suppliers from the world's emerging economies, for example, Asia. Building on stakeholder theory, the current study examines the issue by analyzing the pressures from stakeholders' perspective as primary constituencies of the firm determining the extent to which firms consider social, ecological and economic aspects in the selection of emerging economy suppliers. Based on the data from one of the emerging markets in Asia, the results can be considered as indicative, rather than representative, of Asian supply chains. Based on the analysis of research model, all the eight hypothesized paths except two (suppliers' environmental focus and ethical treatment) were substantiated. These results are slightly different from earlier studies in the developed economies (Thornton et al., 2013; Mishra and Suar, 2010; Carter et al., 1999), where all of these paths were supported. Interestingly, we also found that firms' sustainable supplier selection practices are positively and significantly linked with superior financial performance. Also, the moderating effect of resource investment in sustainability initiatives was found to be significant.

The hypothesized paths that were not supported are $\mathrm{H} 1$ and $\mathrm{H} 2$ : environmental focus and ethical treatment. This might be due to two features of selecting sustainable suppliers. First, anecdotal evidence suggests Thailand as an emerging economy is in the early stage of SSS adoption process. Companies seek short-term profits, while in later stages, companies might seek competitive advantage by adopting such practices. From the managerial perspective, our results suggest that the adoption of SSS is a multidimensional and gradual process rather than a static bundle of policies and practices related to choosing the right suppliers at a specific time. Second, Thailand is an emerging economy where environmental and ethical issues might have a lower priority than other PSR dimensions. However, awareness of the importance of the environmental and ethical treatment is growing.

In line with the stakeholder theory to achieve a combined result from which all the parties can benefit and take responsibility by pursuing the sustainability values of top management, a common desire to mitigate risk and stakeholder management are salient motivators for SSS adoption. Conversely, a lack of supplier awareness, negative perceptions and inadequate management support emerged as barriers to SSS implementation. This commitment to SSS through a cohesive and participative management in Thailand of all the relevant stakeholders can be benefited from the perspective of the theory of stakeholders. Many companies in Thailand are doing business with large MNCs and are increasingly under pressures from stakeholders (i.e. consumers, local government, global partners/alliances and 
competitors). This motivates companies to adopt social and environmental practices to conform to global standards (Ansari et al., 2010). This tendency is aligned with stakeholder theory, which postulated that businesses in emerging economies tend to adopt SSS to survive by reacting to external pressures, rather than proactively embedding SSS in their long-term business strategy and goals.

Finally, this study contributes to the sustainable supply chain management literature in three ways. First, a set of measurement scales for SSS has been adapted from the study by Carter and Jennings (2004) and applied with certain modifications. Second, this study theoretically establishes the link between Carter and Jennings's (2004) PSR variables and SSS, as well as empirically testing their relationships. Third, in earlier studies, Wu and Pagell (2011) found a positive relationship between a firm's sustainable business initiatives and its financial performance in the context of a mature economy. The present study was conducted within an emerging economy context that is culturally and economically different. Rettab et al. (2009) argue that socially and environmentally responsible business practices in emerging economies have little or no significance. Surprisingly, the findings of this study are counterintuitive, suggesting SSS and financial performance are also positively and significantly linked within the context of emerging economies.

This finding implies that by adopting SSS in emerging economies, MNCs and local firms can create a source of differentiation, and hence competitive advantage. Suppliers who do business with MNCs and are pursuing SSS can maintain and enhance their reputation as a qualifier and be a lucrative partner to do business with. This is in line with Porter and Kramer's (2006) argument, and it is through initiatives such as sustainable business practices that a company will have the most significant social impact and reap the greatest business benefits. Finally, building on SSS mechanism and drawing on stakeholder theory, current study adds to the existing body of literature by proactively engaging and communicating with key stakeholders, and having traceability and visibility into upstream supply chain operations can lead to superior financial performance.

Finally, the findings of this study have got macroeconomic implications in line with the sustainable development goals envisioned by the United Nations for the year 2030 . Through adoption of SSS, business would be able to implement responsible production and consumption. This will enable to substantially change toward responsible management throughout the supply chain. SSS is expected to encourage companies, especially large and transnational companies operating in emerging economies, to adopt sustainable practices and to integrate sustainability information into their reporting system. Eventually, SSS will promote public procurement practices in emerging economies that are sustainable, in accordance with national policies and priorities, relevant information and awareness for sustainable development and lifestyles in harmony with nature.

\section{References}

Ansari, S.M., Fiss, P.C. and Zajac, E.J. (2010), "Made to fit: how practices vary as they diffuse", Academy of Management Review, Vol. 35 No. 1, pp. 67-92.

Bhalla, G. and Lin, L.Y. (1987), "Cross-cultural marketing research: a discussion of equivalence issues and measurement strategies", Psychology and Marketing, Vol. 4 No. 4, p. 275.

Blome, C., Hollos, D. and Paulraj, A. (2014), "Green procurement and green supplier development: antecedents and effects on supplier performance", International Journal of Production Research, Vol. 52, pp. 32-49.

Carroll, A.B. (1979), "A three-dimensional conceptual model of corporate social performance", Academy of Management Review, Vol. 4 No. 4, pp. 497-505.
Sustainable supplier selection 
EJMBE 29,3
Carter, R.C. and Easton, P.L. (2011), "Sustainable supply chain management: evolution and future directions", International Journal of Physical Distribution and Logistics Management, Vol. 41 No. 1 , pp. $46-62$.

Carter, C.R. and Jennings, M.M. (2002a), "Logistics social responsibility: an integrative framework", Journal of Business Logistics, Vol. 23 No. 1, pp. 145-180.

Carter, C.R. and Jennings, M.M. (2002b), "Social responsibility and supply chain relationships", Transportation Research Part E: Logistics and Transportation Review, Vol. 38 No. 1, pp. 37-52.

Carter, C.R. and Jennings, M.M. (2004), "The role of purchasing in corporate social responsibility: a structural equation analysis", Journal of Business Logistics, Vol. 25 No. 1, pp. 145-186.

Carter, C.R. and Rogers, D.S. (2008), "A framework of sustainable supply chain management: moving toward new theory", International Journal of Physical Distribution and Logistics Management, Vol. 38 No. 5, pp. 360-387.

Carter, C.R., Auskalnis, R. and Ketchum, C. (1999), "Purchasing from minority business enterprises: a cross-industry comparison of best practices", Journal of Supply Chain Management, Vol. 35 No. 1, pp. 28-32.

Chandler, A.D. (1962), Strategy and Structure: Chapters in the History of the American Industrial Enterprise, Harvard University Press, Cambridge, MA.

Chow, W.S. and Chen, Y. (2012), "Corporate sustainable development: testing a new scale based on the mainland Chinese context", Journal of Business Ethics, Vol. 105 No. 4, pp. 519-533.

Culpan, T., Guglielmo, C. and Apple, H.P. (2010), Dell Begin Probing Supplier after Suicides (Update 2), Business Week, Bloomberg, California.

Chowdhury, R. (2017), "Rana Plaza fieldwork and academic anxiety: some reflections", Journal of Management Studies, Vol. 54 No. 7, pp. 1111-1117.

Cochran, P.L. and Wood, R.A. (1984), "Corporate social responsibility and financial performance", Academy of Management Journal, Vol. 27 No. 1, pp. 42-56.

Donaldson, T. and Preston, L.E. (1995), "The stakeholder theory of the corporation: concepts, evidence, and implications", Academy of Management Review, Vol. 20 No. 1, pp. 65-91.

Elkington, J.L. (1998), Cannibals with Forks: The Triple Bottom Line of 21st-Century Business, New Society Publishers, Stony Creek, CT.

Feng, M., Wang, X. and Kreuze, J.G. (2017), "Corporate social responsibility and firm financial performance: comparison analyses across industries and CSR categories", American Journal of Business, Vol. 32 Nos 3-4, pp. 106-133.

Foerstl, K., Azadegan, A., Leppelt, T. and Hartmann, E. (2015), "Drivers of supplier sustainability: moving beyond compliance to commitment", Journal of Supply Chain Management, Vol. 51 No. 1, pp. 67-92.

Fornell, C. and Larcker, D. (1981), "Evaluating structural equation models with unobservable variables and measurement error", Journal of Marketing Research, Vol. 18, pp. 39-50.

Freeman, R.E., Wicks, A.C. and Parmar, B. (2004), "Stakeholder theory and the corporate objective revisited”, Organization Science, Vol. 15 No. 3, pp. 364-369.

Galbraith, J.R. and Nathanson, D.A. (1978), Strategy Implementation: The Role of Structure and Process, West Publishing Company, St, Paul, MN.

Gefen, D. and Straub, D. (2005), "A practical guide to factorial validity using PLS-graph: tutorial and annotated example", Communications of the Association for Information Systems, Vol. 16 No. 1, pp. 91-105.

Hair, J.F., Black, W.C., Babin, B.J. and Anderson, R.E. (2010), Multivariate Data Analysis, 5th ed., Prentice Hall, Upper Saddle River.

Hair, J.F., Hult, G.T.M., Ringle, C.M. and Sarstedt, M. (2017), A Primer on Partial Least Squares Structural Equation Modeling (PLS-SEM), 2nd ed., Thousand Oaks: Sage, CA. 
Hayes, A.F. (2013), Introduction to Mediation, Moderation, and Conditional Process Analysis: A Regression-Based Approach, Guilford Press, New York.

Henseler, J., Dijkstra, T.K., Sarstedt, M., Ringle, C.M., Diamantopoulos, A., Straub, D.W. and Calantone, R.J. (2014), "Common beliefs and reality about PLS: comments on rönkkö and evermann (2013)", Organizational Research Methods, Vol. 17 No. 2, pp. 182-209.

Hofmann, H., Busse, C., Bode, C. and Henke, M. (2014), "Sustainability-related supply chain risks: conceptualization and management", Business Strategy and The Environment, Vol. 23 No. 3, pp. 160-172.

Hu, L.T. and Bentler, P.M. (1999), "Cutoff criteria for fit indexes in covariance structure analysis: conventional criteria versus new alternatives", Structural Equation Modeling: A Multidisciplinary Journal, Vol. 6 No. 1, pp. 1-55.

Koplin, J., Seuring, S. and Mesterharm, M. (2007), "Incorporating sustainability into supply management in the automotive industry - the case of the volkswagen AG", Journal of Cleaner Production, Vol. 15 Nos 11/12, pp. 1053-1062.

Kumar, D. and Rahman, Z. (2016), "Buyer supplier relationship and supply chain sustainability: empirical study of Indian automobile industry", Journal of Cleaner Production, Vol. 131, pp. 836-848.

McKinsey and Co (2014), "Sustainability's strategic worth", McKinsey Global Survey results, available at: http://www.mckinsey.com/business-functions/sustainability-and-resource-productivity/ourinsights/sustainabilitys-strategic-worth-mckinsey-global-survey-results (accessed 11 June 2019).

McGuire, J.B., Sundgren, A. and Schneeweis, T. (1988), "Corporate social responsibility and firm financial performance”, Academy of Management Journal, Vol. 31, pp. 854-872.

Miles, R.E. and Snow, C.C. (1984), Organizational Strategy, Structure, and Process, McGraw-Hill, New York.

Mishra, S. and Suar, D. (2010), "Does corporate social responsibility influence firm performance of Indian companies?”, Journal of Business Ethics, Vol. 95 No. 4, pp. 571-601.

Monczka, R.M., Trent, R.J. and Petersen, K.J. (2008), "Getting on track to better global sourcing", Supply Chain Management Review, Vol. 12 No. 2, pp. 46-53.

Munro, V., Arli, D. and Rundle-Thiele, S. (2018), "CSR engagement and values in a pre-emerging and emerging country context”, International Journal of Emerging Markets, Vol. 13 No. 5, pp. 1251-1272.

Nunnally, J. (1978), Psychometric Theory, McGraw-Hill, New York.

Panahifar, F., Byrne, P.J., Salam, M.A. and Heavey, C. (2018), "Supply chain collaboration and firm's performance", Journal of Enterprise Information Management, Vol. 31 No. 3, pp. 358-379.

Porter, M.E. and Kramer, M.R. (2006), "Strategy and society: the link between competitive advantage and corporate social responsibility", Harvard Business Review, Vol. 84 No. 12, pp. 78-92.

Preston, L.E. and O'bannon, D.P. (1997), "The corporate social-financial performance relationship: a typology and analysis", Business and Society, Vol. 36 No. 4, pp. 419-429.

Rettab, B., Brik, A.B. and Mellahi, K. (2009), "A study of management perceptions of the impact of corporate social responsibility on organizational performance in emerging economies: the case of Dubai”, Journal of Business Ethics, Vol. 89 No. 3, pp. 371-390.

Reuter, C., Foerstl, K., Hartmann, E. and Blome, C. (2010), "Sustainable global supplier management: the role of dynamic capabilities in achieving competitive advantage", Journal of Supply Chain Management, Vol. 46 No. 2, pp. 45-63.

Thornton, L.M., Autry, C.W., Gligor, D.M. and Brik, A.B. (2013), "Does socially responsible supplier selection pay off for customer firms? A cross-cultural comparison", Journal of Supply Chain Management, Vol. 49 No. 3, pp. 66-89.

Walker, H. and Jones, N. (2012), "Sustainable supply chain management across the UK private sector", Supply Chain Management: An International Journal, Vol. 17 No. 1, pp. 15-28. 
EJMBE 29,3

\section{2}

Wu, Z. and Pagell, M. (2011), "Balancing priorities: decision-making in sustainable supply chain management", Journal of Operations Management, Vol. 29 No. 6, pp. 577-590.

Yu, W., Yu, I.T.S., Li, Z., Wang, X., Sun, T., Lin, H., Wan, S., Qiu, H. and Xie, S. (2012), "Work-related injuries and musculoskeletal disorders among factory workers in a major city of China", Accident and Analysis Prevention, Vol. 48 No. 1, pp. 457-463.

Yuan, H., Rong, F. and Ying, D. (2010), "China's environment accidents double on growth toll", Business Week, Bloomberg, California.

\section{Further reading}

Calantone, R.J. (2014), "Common beliefs and reality about PLS: comments on rönkkö and evermann (2013)”, Organizational Research Methods, Vol. 17 No. 2, pp. 182-209.

Carter, C.R. (2005), "Purchasing social responsibility and firm performance: the key mediating roles of organizational learning and supplier performance", International Journal of Physical Distribution and Logistics Management, Vol. 35 No. 3, pp. 177-194.

\section{Corresponding author}

Mohammad Asif Salam can be contacted at: mbamas@yahoo.com

For instructions on how to order reprints of this article, please visit our website: 